\title{
The Impact of Problem-Based Learning on Iranian EFL Learners' Speaking Proficiency
}

\author{
Loghman Ansarian (Corresponding author) \\ School of Foreign Langauges, Tabriz Payame Noor University, Iran \\ E-mail: Loghmanelt@yahoo.com \\ Ali Akbar Adlipour \\ School of Foreign Languages, Tabriz Payame Noor University, Iran \\ E-mail: Adlipour@yahoo.com \\ Mehrnoush Akhavan Saber \\ School of Foreign Languages, Gheshm Payame Noor University, Iran \\ E-mail: Mehr1077@gmail.com \\ Elmira Shafiei \\ School of Foreign Languages, Gheshm Payame Noor University, Iran \\ E-mail: Elmira_Shafiei@yahoo.com
}

Doi:10.7575/aiac.alls.v.7n.3p.84

URL: http://dx.doi.org/10.7575/aiac.alls.v.7n.3p.84
Received: 28/01/2016

Accepted: 05/03/2016

\begin{abstract}
The study investigated the effect of problem-based learning through cognition-based tasks on speaking proficiency of Iranian intermediate EFL learners in comparison to the effect of objective-based tasks. To this end, a true experimental research design was employed. Ninety five $(\mathrm{N}=95)$ language learners studying at a language institute in the city of Esfahan, Iran were given an IELTS listening and speaking test as the proficiency test and 75 learners were selected. In the next phase of the study, a second IELTS speaking test was administered as the homogeneity test and the pre-test to seventy five $(\mathrm{N}=75)$ learners chosen from the population and forty-eight $(\mathrm{N}=48)$ homogeneous intermediate learners were selected for the study (i.e., 24 learners in control group and 24 in experimental one). The results of an independent-sample t-test gained from the study proved that not only does implementation of problem-based learning through cognition-based tasks significantly increased intermediate participants' speaking proficiency, but also it had more positive effect in comparison to objective-based tasks on participants' speaking proficiency. Therefore, it is suggested that problem-based learning ought to be taken into account by educational scholars, those in charge of syllabus, material producers, language teachers and language learners.
\end{abstract}

Keywords: Cognition-Based Tasks, Objective-Based Tasks, EFL Learners, Speaking Proficiency, Problem-Based Learning

\section{Introduction}

Problem-based learning emerged as a reform in education in 1970s. As mentioned by Savery (2006, p. 9), "it stood against the intensive lecture-based courses followed by exhausting sessions in the field of medicine at McMaster University in Canada in 1969". The underlying assumption of PBL was "to stay away from the standard building-block structure, where a lot of content is shoved down the throats of the students, which they do not retain anyway and adopt a system where students are actively involved in the learning process" (Robert \& Kwan, 1997, p. 149). This strong underlying assumption led PBL to be widely used within medicine and business, PBL soon gained popularity in other academic disciplines such as biology and physics and to a lesser degree in history and geography (Larsson, 2001).

Given EFL/ESL contexts, the fact that PBL can be possibly used to practice on students communicative skills (Larsson, 2001) sparked the first ideas about using PBL in order to enhance students' communicative skills. Yet, a very important issue should be considered. Communication in the second language has a different psychological base and the use of language in the second language is different from the first language. Larsson (2001) explains that language is a tool when learning not a subject of it.

According to Woods et al. (1996), PBL started as a reaction to lecture-based teaching since research in educational psychology has found that traditional educational approaches (e.g., lectures) do not lead to great knowledge retention. Despite intense efforts on the part of both learners and instructors, most material learned through lectures is soon forgotten, and natural problem solving abilities may actually be impaired. In fact, studies have shown that students forget $90 \%$ of what they are told during 90 days (Smilovitz, 1996). 
Moreover, current language teaching methods used in EFL/ESL settings have a number of shortcomings which has hindered the maximum outcome in courses. First of all, language teaching methods ranging from grammar translation method (GTM) to recent task-based approaches all are over-reliant on language teachers; meaning that there is a crucial defined role for the teachers in these approaches which can reduce the outcome of the course (Kumaravadivelu, 1984). Also, various activities such as explaining, describing, decoding, guiding etc. occur in language courses. Such activities carried out by the teachers, as explained in cognitive psychology, reduced students' ability to decode, analyze and solve the problems (Savery, 2006). In addition, these activities reduce student talk-time and increase teachers' time which is not considered a suitable time division in the classroom.

Moreover, a quick look at approaches in the field of language teaching reveals that not all of them are suitably learning or learner-based, though new findings in educational psychology especially with regard to cognition and meta-cognition have proved that teaching and learning approaches that consider students organizing, planning, and problem-solving ability can more effectively deliver education (Anita et.al, 2013).

Thus, the primary concern of the study was to delve into the effect of tutored PBL on Iranian intermediate EFL learners' speaking proficiency. This was done by considering four fundamental elements in EFL learners' speech; namely, pronunciation, coherence and cohesion, lexical resources, and grammatical accuracy. In order to pursue the purposes of this study, the following research questions were proposed:

Q1: Does implication of tutored problem-based learning through cognition-based tasks have any effect on Iranian intermediate EFL learners' speaking proficiency?

Q2: Does implication of tutored problem-based learning through cognition-based tasks have more positive effect than implication of objective-based tasks on Iranian intermediate EFL learners' speaking proficiency?

Accordingly, the following hypotheses were to be tested in this study:

H01: Implication of tutored problem-based learning through cognition-based tasks has no effect on Iranian EFL learners' speaking proficiency at intermediate level.

H02: Implication of tutored problem-based learning through cognition-based tasks does not have more positive effect than objective-based tasks on Iranian EFL learners' speaking proficiency at intermediate level.

\section{Literature Review}

Problem-based approaches to learning have a long history. They are one of many instructional approaches that situate learning in a meaningful task, such as case-based instruction and project-based learning. According to Kilpatrick (1918, 1921) and Dewey (1938), these approaches emphasize the importance of experience in learning. They emphasize that, PBL refers to meaningful and experiential learning and students learn by solving problems and reflecting on their experiences.

Barrows and Tamblyn (1980) argue that PBL helps students become active learners by placing the learning in realworld problems and making students responsible for their learning. It has a dual emphasis on helping learners develop strategies and construct knowledge (Collins et al., 1989; Kolodner et al., 1996). PBL is of great interest to educators because of its emphasis on active, transferable learning and its potential for motivating students (e.g., Duch et al., 2001; Torp \& Sage, 2002).

PBL had promising premises such as (1) a strong and well-founded psychological background in cognitive psychology; (2) centrality of learning and learners in the classrooms; (3) diminished role of teachers (tutors) and prominent role of learners; (4) the special role for self and peer assessment of newly learned materials; (5) re-placement of memorization with conceptualization and retention of data; and (6) its high construct validity. Such features, eventually, caused this approach to be adopted by scholars in other disciplines in educational systems other than those of North America (Robert \& Kwan, 1997).

PBL is a learner-centered method and the PBL teacher is a facilitator of student learning, and his/her interventions decrease as soon as the students take the responsibility for their own learning. This method is carried out in small groups through discussion, problem solving, and study with peers (Lesgold et al., 1988; Hmelo-Silver, 2004; Novick \& Hmelo, 1994). The teacher guides the students in the learning process, helps them think deeply, and models the questions that students should ask themselves, thus, forming a cognitive apprenticeship (Collins et al., 1989).

\subsection{The Goals of PBL}

Problem-based curricula aim at preparing the students to solve real-life problems. This can justify what the goals in this approach are. As discussed by (Barrows \& Kelson, 1995) PBL aims at:

1) Constructing an extensive and flexible knowledge base;

2) Developing effective problem-solving skills;

3) Developing self-directed, lifelong learning skills;

4) Becoming effective collaborators;

5) Becoming intrinsically motivated to learn. 
The belief in PBL is that constructing knowledge involves integrating information across multiple domains and that knowledge can be applied under various circumstances (Bransford et al., 1990). Flexible knowledge can develop by individuals' application of their knowledge in various problem situations (Kolodner, 1993). Real-life context in which knowledge can be practically used is essential for learning. Laboratory experiments have demonstrated that this is, indeed, the case (e.g., Needham \& Begg, 1991; Perfetto et al., 1983). Discussing problems in a PBL group at the early stages of a PBL process activates prior knowledge. Hence, it makes the learning process easier (Schmidt et al., 1989). Students are better able to construct new knowledge when they can relate it to what they already know (Bransford \& McCarrell, 1977).

The PBL learning cycle is enacted through the tutorial process that begins with the presentation of a problem and ends with student reflection. A PBL tutorial session begins by presenting a group of students with minimal information about a complex problem (Barrows, 2000). From the outset, students must question the facilitator to obtain additional problem information; they may also gather facts by doing experiments or other research (Torp \& Sage, 2002). In addition, the PBL tutorial process helps support knowledge construction as students are guided through their learning and problemsolving processes. As students begin to discuss a problem with a na"1ve understanding, they activate their prior knowledge, which helps prepare them for learning (Schmidt et al., 1989). It also facilitates the social construction of knowledge as learners work in small groups using their inquiry skills to solve real-world problems (Greeno et al., 1996).

\subsection{Developing Effective Problem-Solving Skills}

One of the features of problem-solving skills is the ability to transfer reasoning strategies to new problems. According to Patel et al. (1991, 1993), students in the PBL curriculum are more likely to use hypothesis-driven reasoning (as they were taught) than were students in a traditional curriculum. The students in the traditional medical school used datadriven reasoning more often (Norman et al., 1994, 1998).

In addition, problem-solving skills include being able to define the problem which is one of the aspects of problem solving and refers to the problem identification. Gallagher et al. (1992) compared the problem solving skills of the gifted students with students in a PBL class and found that PBL students used problem finding while encountering with a new problem more often. They also concluded that students in PBL learn problem-solving and reasoning strategies which can be transferred to new problems.

Relating problem solving and learning is an important element in PBL and is needed for the construction of flexible knowledge (Salomon \& Perkins, 1989). This reflection should help learners understand the relationship between their learning and problem-solving goals. Thus, each problem-solving task is not an end in itself but rather a means to achieve a self-defined learning goal (Bereiter \& Scardamalia, 1989).

Through reflection, students can relate new knowledge to prior understanding and they can understand how their learning and problem-solving strategies might be used. PBL utilizes reflection many times in the tutorial process for completing a problem. When completing the problem, students reflect on what they have learned, how well they cooperated with the group, and how effectively they directed their learning. Students can have a more coherent understanding when they make inferences on how general concepts and skills are connected to the specifics of the problem that they are working on (Chi et al., 1989). To develop such understanding, students should reflect on their knowledge and strategies and that reflection in PBL helps students make inferences; find gaps in their thinking; and transfer their problem-solving strategies and knowledge to new situations.

\subsection{Developing SDL Skills}

One of the benefits of PBL is its claim to help learners enhance self-directed learning (SDL). Becoming a self-directed learner is a multifaceted process. Students in a PBL curriculum become more self-reliant. According to Blumberg and Michael (1992), PBL students use more self-selected learning resources instead of the resources selected by the faculty. PBL students were more likely to report their own selection of the material to study, whereas conventional curriculum students reported reading specific teacher-generated assignments. Students in a PBL course in sustainable technology increased their use of expertise and tended to use a variety of student-selected resources (Shikano \& Hmelo, 1996).

The research in PBL has largely been limited to professional students; however, all the students need to cope with the uncertainty involved in their learning. For students who are self-regulated, PBL can create difficulties if appropriate scaffolding is not given to those trying to develop SDL skills. Enhancing and scaffolding SDL is very important for younger learners. As Evensen (2000) and Evensen et al. (2001) demonstrated, students' SDL strategies evolve over time.

\subsection{Collaborative Learning in $P B L$}

Collaborative problem-solving groups are a key feature of PBL. In other words, through the small group structure, the cognitive load is reduced among the members of the group and the whole group solves problems that are too difficult to cope with alone (Pea, 1993; Salomon, 1993). The notion of distributed expertise is particularly relevant in PBL because as the students divide up the learning issues they become experts in particular topics. Furthermore, research suggests that the small group discussions and debate in PBL sessions enhances problem solving and higher order thinking and promotes shared knowledge construction (Blumenfeld et al., 1996; Brown, 1995; Vye et al., 1997). Working in group is very important because it enhances the learning outcomes and intrinsic motivation (Schmidt \& Moust, 2000). 
There is not yet evidence that supports the hypothesis that PBL helps students become better collaborators (broadly defined). There is evidence that students do work together to provide collaborative explanations as demonstrated in the example from Hmelo-Silver (2002). There is also evidence that demonstrates that collaboration in tutorial groups is a key factor in student learning and motivation, but that not all groups collaborate well.

\subsection{Becoming Intrinsically Motivated}

Enhancing students' motivation is purported to be a major advantage of PBL. Unfortunately there is little research that bears directly on this issue. Most of the research has instead examined student satisfaction or confidence (Derry et al., 2000). Some students really enjoy the class but others resist changing their way of learning or do not like working collaboratively. In interviews with veterinary students, Ertmer et al. (1996) found the evidence of intrinsic motivation associated with PBL but the nature of students' motivation in PBL may depend on their academic or professional discipline (Abrandt Dahlgren \& Dahlgren, 2002). Students in PBL curricula report being more satisfied with their learning than those in traditional curricula (Albanese \& Mitchell, 1993; Vernon \& Blake, 1993).

\subsection{Teacher's Role as the Facilitator}

In PBL, the teacher is a facilitator who is an expert learner and presents good strategies for learning and thinking. The facilitator scaffolds and helps students' learning through modeling and the use of questioning strategies (Hmelo-Silver \& Barrows, 2003; Hmelo \& Ferrari, 1997). Facilitators decrease their scaffolding when students become more experienced with PBL and adopt most of the facilitators' roles. The facilitator is responsible for guiding the students in the stages of PBL and controlling the group process. Through monitoring, all the students are involved and encouraged to vocalize their own thinking and comment on each other's (Hmelo-Silver, 2000, 2002; Koschmann, 1999; Koschmann et al., 1994, 1999). The PBL facilitator helps the learners enhance higher order thinking, encourages them to justify their thinking, and develops self-reflection by posing appropriate questions.

\subsection{Empirical Background}

Much of the evidence represented in this section comes from research in medical schools and gifted education although there are a few studies involving other populations. PBL is used in various settings such as administration, business, psychology, engineering, chemistry, etc. (Boud \& Felletti, 1991; Bridges, 1992; Duch et al., 2001; Hmelo et al., 1995; Ram, 1999; Stepien \& Gallagher, 1993;Torp \& Sage, 2002), but there is less empirical evidence as to what students are learning and how.

Research studies have explored PBL students' performance on problem-solving tasks (Hmelo, 1998; Hmelo et al., 1997). Patel et al.'s (1991, 1993) study indicated that the PBL students' explanations, although more error-prone, were also more elaborated than those of the medical students in traditional curricula. This result is consistent with research that demonstrated that as people are first attempting to apply new knowledge, they do not always do it well (Lesgold et al., 1988). Chi et al. (1994) suggest that errors are a necessary step in learning to apply new knowledge. By articulating incorrect knowledge, learners have the opportunity to revise their false beliefs when they are confronted with correct knowledge. The research suggests an advantage in having a well elaborated knowledge structure that contains some errors instead of having little elaborated knowledge that cannot be applied.

Hmelo (1998) conducted a quasi-experimental study that compared students who self-selected into traditional and PBL tracks at a mid-western medical school. In this study, the students provided explanations for problems in three testing sessions during the 1st week of classes, and again after 3 and 7 months. Their explanations were rated for accuracy, coherence, and use of science concepts. The students did not differ on any of these measures at the initial testing session. It was concluded that the students in the PBL curriculum produced more accurate and coherent explanations than students in the traditional curriculum. In addition, they were more likely to use science concepts in their explanations. This suggests that the PBL students were constructing knowledge that they could bring to bear in accurately solving problems. Their science knowledge was flexible in that they were able to transfer it to new problem situations.

Schwartz and Bransford (1998) conducted a controlled study of students in an undergraduate psychology course. They compared students in three groups: (1) students who just solved problems, (2) students who read a textbook chapter prior to attending a lecture, and (3) students who solved problems prior to attending a lecture. They found that students who solved problems prior to the lecture performed better on a problem-solving task than students who read the chapter or those who just solved problems. This finding suggests that attempting to solve a problem helps create a readiness to learn from a lecture.

Gallagher and Stepien (1996) compared students in a problem-based course with those in a traditional class. The PBL students scored higher on a multiple-choice test than traditionally instructed students. In other words, students retained the information presented in PBL units better than information from traditional units, despite the fact that the students thought they learned more in lecture-based units.

In a study with sixth-grade students, Hmelo et al. (2000), in collaboration with classroom teachers, developed a PBL unit that involved students designing artificial lungs. The results indicated that PBL students outperformed in both short-answer tests and a drawing task. However, the students in the PBL class had some misunderstandings at the end of the 3-week unit. The results of this research suggest that in the use of PBL in appropriate ways, some adaptions are needed and that varying kinds of scaffolding might be needed to help children learn while tackling complex problems. Thus, direct instruction is needed with less uniformly skilled learners. 


\section{Method}

\subsection{Participants}

The participants for the study were chosen randomly among ninety five $(\mathrm{N}=95)$ adult intermediate Iranian $\mathrm{EFL}$ learners who were studying at Kavosh language institute in Esfahan, Iran. The age range of participants was between 17-21, though age was not a factor in this study.

In order to choose the intermediate participants for the study, an IELTS listening test and an IELTS speaking test were administered to the population. Seventy-five $(\mathrm{N}=75)$ intermediate learners were chosen among the total population $(\mathrm{N}=95)$. Next, a second IELTS speaking test was administered to the participants in order to homogenize them based on the speaking proficiency and to be used as the pretest. Considering $1 \mathrm{SD}$ below and above the mean score, forty-eight $(\mathrm{N}=48)$ intermediate learners were selected for the study. Three raters, including two M.A. holders with 5 years of experience in the field of language teaching and a native speaker with 5 years of experience in teaching EFL courses, scored the speaking section on a scale of 1 to 30 . In addition, correlation of the scores given by the raters was calculated to make sure the scores given by raters has justified reliability.

\subsection{Instruments}

Three different instruments were used in this study. IELTS speaking and listening test was administered to the population in order to homogenize them based on their level of proficiency; namely, intermediate. IELTS test is a highly valid English proficiency test administered by Cambridge University all around the world.

Moreover, Top Notch English series was used to be taught in the control group. The series was designed by John Saslow and Alan Ascher (2008) and is one of the most widespread series used in Iran's EFL context. The focus of the series is on communication. Each lesson consists of two types of conversations (standardized and natural), grammar, pronunciation, vocabulary sections, and an extra page at the end of each unit which aims at conversations production by the students based on a photo. Furthermore, Modified Top Notch Series was used in the experimental groups. This was Top Notch series written by John Saslow and Allen Asher but the researcher has applied certain changes to the book in order to make it compatible with cognition-based teaching approach. The main difference was omission of conversations and adding problem-scenarios instead.

\subsection{Procedure}

Implementing a PBL process requires designing meticulous steps. In order to do so, the study was piloted in 4 sessions. After piloting the study, the researcher implemented two necessary changes in the treatment. The first was with regard to the problem scenario. The researcher made the problems more implicit in order to avoiding decoding of the problem by the description of the problem. The second change was in the timing and amount of help offered to the learners by the tutor. Learners frequently ask the instructor questions to be able to decode the problem. After a close study of the learners' behavior the researcher came to the conclusion that learners should only be aided after they have used any source at their disposal to solve the problem including their own cognition, peers help, online and paperback sources etc.

In the main study, an IELTS listening and speaking test was administered 95 learners and 75 intermediate learners were chosen. After selecting the participants for the study by administering listening and speaking tests, the study entered its second phase. In the second phase of the study, the selected participants took a second IELTS speaking test to: (1) make sure the data collected is statistically significant and has not occurred by chance and, (2) To be used as the pretest data for the study. Based on the second test, 48 homogeneous intermediate learners were selected for the study. The third phase of the study was implementing PBL treatment is experimental group by using cognition-based tasks and implementing objective-based tasks in control groups by using objective-based tasks which took twenty sessions. After that, the participants took an IELTS speaking proficiency test as the posttest.

All interviews with the participants were recorded and analyzed by the raters. In order to avoid the researcher expectancy effect, the audio files went through a blind review process, so the raters did not know which participant is which. The audio files were scored on the scale of 1 to 30 for each of the factors discussed in the study; namely, pronunciation, fluency and coherence, lexical resources, and grammatical accuracy. The results gathered from the pretests and the posttests were compared using SPSS software in order to find answers to the research questions.

\subsection{Design of the Study}

The study aimed at finding out if tutored problem-based learning had any effect on speaking proficiency of intermediate Iranian EFL learners quantitatively. Thus, the researcher made use of a true experimental design. True-experimental studies are used in cases where there is a control group and randomization in choosing participants. 2 groups of participants formed for this study went through two different types of teaching as experimental group by using cognition-based tasks, and control group by using objective-based tasks. Thus, the independent variables in the study are cognition-based tasks and objective-based tasks and the dependent variable is speaking proficiency of intermediate participants.

\subsection{Data Analysis}

SPSS was used to analyze the data gathered from the participants as the study is a quantitative one. In the first phase of the data analysis, the distribution of the data on the speaking and listening test was checked in order to make sure the assumption of the study which is a parametric one based on a normal distribution of data is met. Next, inter-rater 
reliability of the speaking test which was scored by 3 raters was gauged using correlations on SPSS. The participants pretest and posttest results were then compared using paired-samples $t$-test to compare the experimental group in pretest and posttest and an independent-samples t-test in pretest and posttest to compare control and experimental groups.

\section{Results}

In order to analyze the relevant data, the researcher used Statistical Package for Social Sciences (SPSS) including Cronbach's Alpha and a series of an independent-samples $t$-test.

4.1 Quantitative Data Analysis for the Proficiency Test

An IELTS listening and speaking test was administered to ninety-five $(\mathrm{N}=95)$ students studying as intermediate students. Although IELTS is a reliable test, Cronbach's Alpha Index was used to gauge the reliability of the listening test.

Table 4.1 Cronbach's Alpha for the Proficiency Test

\begin{tabular}{lcc}
\hline \multicolumn{2}{c}{ Cronbach's Alpha } & N of Items \\
\hline Intermediate & .81 & 40 \\
\hline
\end{tabular}

The Cronbach's Alpha indicated that the test for intermediate learners was reliable enough $(\alpha=0.81)$.

\subsection{Quantitative Data Analysis for the First Research Question}

In order to answer the first research question stating whether implication of tutored problem-based learning through cognition-based tasks has any effect on Iranian EFL learners' speaking proficiency at intermediate level, a pairedsamples t-test was run to compare experimental intermediate participants' performance on the pretest and the posttest.

Table 4.2 Descriptive Statistics for the Effect of Cognition-Based Tasks on intermediate participants

\begin{tabular}{llllll}
\hline & & Mean & $\mathrm{N}$ & Std. Deviation & Std. Error Mean \\
\hline \multirow{2}{*}{ Pair 1 } & Intermediate Posttest & 18.58 & 24 & 1.05981 & .21633 \\
\cline { 2 - 6 } & Intermediate Pretest & 15.75 & 24 & 1.15156 & .23506 \\
\hline
\end{tabular}

According to the mean scores, there was a significant difference between pre-test and post-test.

Table 4.3 Paired-Samples T-test for Effect of Cognition-Based Tasks Intermediate participants

\begin{tabular}{|c|c|c|c|c|c|c|c|c|c|}
\hline & & \multicolumn{5}{|c|}{ Paired Differences } & \multirow[b]{3}{*}{$\mathrm{t}$} & \multirow[b]{3}{*}{$\mathrm{df}$} & \multirow{3}{*}{$\begin{array}{l}\text { Sig. (2- } \\
\text { tailed) }\end{array}$} \\
\hline & & \multirow[b]{2}{*}{ Mean } & \multirow{2}{*}{$\begin{array}{l}\text { Std. } \\
\text { Deviation }\end{array}$} & \multirow{2}{*}{$\begin{array}{l}\text { Std. } \\
\text { Mean }\end{array}$} & \multicolumn{2}{|c|}{$\begin{array}{l}95 \% \text { Confidence Interva } \\
\text { of the Difference }\end{array}$} & & & \\
\hline & & & & & Lower & Upper & & & \\
\hline Pair 1 & Intermediate & 2.83 & 1.049 & .214 & 2.390 & 3.276 & 13.22 & 23 & .00 \\
\hline
\end{tabular}

A paired-samples t-test indicated a statistically significant increase from pre-test $(\mathrm{M}=\mathrm{M}=15.75, \mathrm{SD}=1.15)$ to post-test $[\mathrm{M}=18.58, \mathrm{SD}=1.05, \mathrm{t}(23)=13.22, \mathrm{p}=.00]$, thus, the first null hypothesis stating that implication of tutored problembased learning through cognition-based tasks has no effect on Iranian EFL learners' speaking proficiency at intermediate level is rejected.

\subsection{Quantitative Data Analysis for the Second Research Question}

In order to find the answer to the second research question stating whether there is a difference between the implication of tutored problem-based learning through cognition-based tasks and objective-based tasks on Iranian EFL learners' speaking proficiency at intermediate level, an independent-sample t-test was run first to make sure the two groups that went through cognition-based instruction as the experimental group and the objective-based instruction as the control group were not significantly different (Table 4.4).

4.4 Descriptive Statistics for the Difference between Cognition-Based Tasks and Objective-Based Tasks in Pretest Intermediate Level

\begin{tabular}{llllll}
\hline & Groups & $\mathrm{N}$ & Mean & Std. Deviation & Std. Error Mean \\
\hline \multirow{2}{*}{ Intermediate } & Control & 24 & 15.66 & 1.239 & .253 \\
\cline { 2 - 6 } & Experimental & 24 & 15.75 & 1.151 & .235 \\
\hline
\end{tabular}


As shown in tables 4.4, intermediate participants' scores in both control group and experimental group did not differ significantly and an independent-samples t-test was employed to confirm it (see Table 4.5).

Table 4.5 Independent Samples Test for the Difference between Cognition-Based Tasks and Objective-Based Tasks in Pretest Intermediate Level

\begin{tabular}{|c|c|c|c|c|c|c|c|c|c|c|}
\hline & & \multicolumn{9}{|c|}{$\begin{array}{l}\text { Levene's Test } \\
\text { for Equality } \\
\text { of Variances } t\end{array}$} \\
\hline & & & & & & & & & \multicolumn{2}{|c|}{$\begin{array}{l}95 \% \text { Confidence } \\
\text { Interval of the } \\
\text { Difference }\end{array}$} \\
\hline & & $\mathrm{F}$ & Sig. & $\mathrm{t}$ & $\mathrm{df}$ & $\begin{array}{l}\text { Sig. } \\
(2- \\
\text { tailed })\end{array}$ & $\begin{array}{l}\text { Mean } \\
\text { Differe } \\
\text { nce }\end{array}$ & $\begin{array}{l}\text { Std. Error } \\
\text { Difference }\end{array}$ & Lower & Upper \\
\hline \multirow[t]{2}{*}{ Intermediate } & $\begin{array}{l}\text { Equal } \\
\text { variances } \\
\text { assumed }\end{array}$ & .26 & .60 & -.24 & 46 & .81 & -.083 & .345 & -.778 & .611 \\
\hline & $\begin{array}{l}\text { Equal } \\
\text { variances } \\
\text { not assumed }\end{array}$ & & & -.24 & 45.7 & .81 & -.083 & .345 & -.778 & .611 \\
\hline
\end{tabular}

An independent-samples t-test was conducted to compare the scores of experimental and control groups in intermediate level. There was no significant difference in scores for experimental $(\mathrm{M}=15.75, \mathrm{SD}=1.15)$ and control group $[\mathrm{M}=15.66, \mathrm{SD}=1.23 ; \mathrm{t}(46)=-.24, \mathrm{p}=.81>.05]$, that is, both groups were homogeneous.

Table 4.6 Descriptive Statistics for the Difference between Cognition-Based Tasks and Objective-Based Tasks in Posttest in Intermediate Level

\begin{tabular}{llllll}
\hline & Groups & $\mathrm{N}$ & Mean & Std. Deviation & Std. Error Mean \\
\hline \multirow{2}{*}{ Intermediate } & Control & 24 & 16.29 & .690 & .140 \\
\cline { 2 - 6 } & Experimental & 24 & 18.58 & 1.05 & .216 \\
\hline
\end{tabular}

According to the mean scores, there was a difference between intermediate control and experimental groups and an independent-samples $t$-test was employed to confirm it (see Table 4.7).

Table 4.7 Independent Samples Test for the Difference between Cognition-Based Tasks and Objective-Based Tasks in Posttest in Intermediate Level

\begin{tabular}{|c|c|c|c|c|c|c|c|c|c|c|}
\hline & & \multicolumn{2}{|c|}{$\begin{array}{l}\text { Levene's Test } \\
\text { for Equality } \\
\text { of Variances }\end{array}$} & \multicolumn{5}{|c|}{ t-test for Equality of Means } & \multirow{2}{*}{\multicolumn{2}{|c|}{$\begin{array}{l}95 \% \text { Confidence } \\
\text { Interval of th } \\
\text { Difference }\end{array}$}} \\
\hline & & & & & & & & & & \\
\hline & & $\mathrm{F}$ & Sig. & $\mathrm{t}$ & $\mathrm{df}$ & $\begin{array}{l}\text { Sig. } \\
\text { tailed) }\end{array}$ & $\begin{aligned} & \text { Mean } \\
& \text { (2- Differenc } \\
& \mathrm{e}\end{aligned}$ & $\begin{array}{l}\text { Std. } \\
\text { Error } \\
\text { Differenc } \\
\text { e }\end{array}$ & Lower & Upper \\
\hline \multirow[t]{2}{*}{ Intermediate } & $\begin{array}{l}\text { Equal } \\
\text { variances } \\
\text { assumed }\end{array}$ & 5.48 & .02 & -8.87 & 46 & .00 & -2.291 & .258 & -2.811 & -1.772 \\
\hline & $\begin{array}{l}\text { Equal } \\
\text { variances not } \\
\text { assumed }\end{array}$ & & & -8.87 & 39.5 & .00 & -2.291 & .258 & -2.813 & -1.769 \\
\hline
\end{tabular}

An independent-samples t-test was conducted to compare the scores of intermediate experimental and control groups in posttest. There was a significant difference in scores for experimental $(\mathrm{M}=18.58, \mathrm{SD}=1.05)$ and control group 
$[\mathrm{M}=16.29, \mathrm{SD}=.69 ; \mathrm{t}(46)=-8.87, \mathrm{p}=.00<.05]$, that is, the experimental group outperformed the control group and the second hypothesis stating that implication of tutored problem-based learning through cognition-based tasks does not have more positive effect than objective-based tasks on Iranian EFL learners' speaking proficiency at intermediate level, is rejected. Figure 4.1 shows the difference between experimental and control groups in post-test.

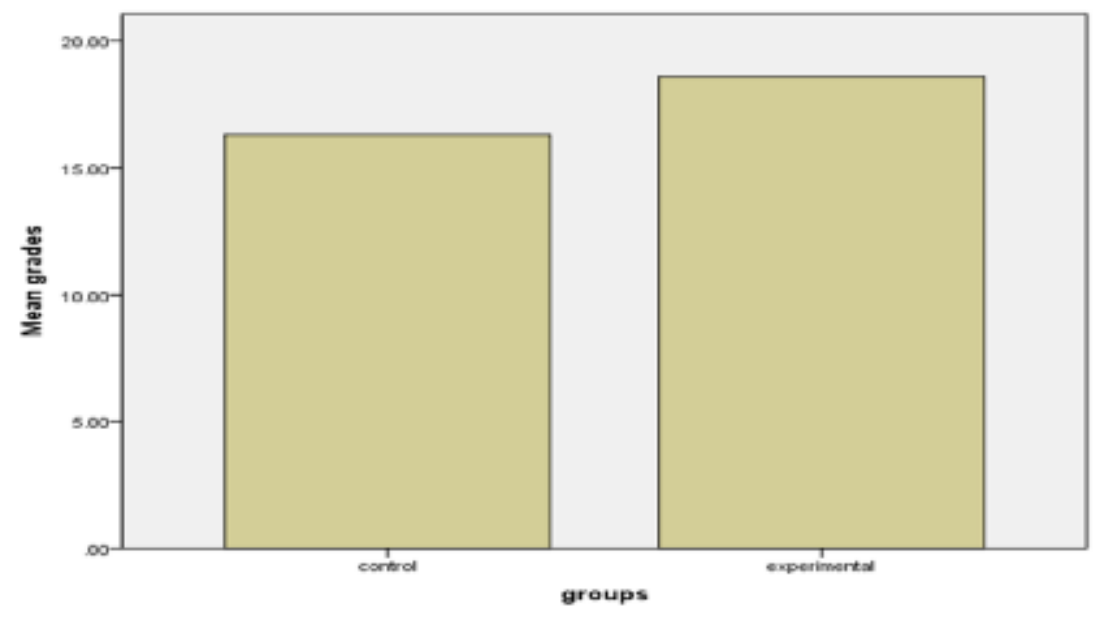

Figure 4.1. The Difference in Mean Scores of the Intermediate Experimental and Control Groups

Figure 4.1 indicates that the mean score of the experimental group was higher than the control one.

\section{Discussion}

The study investigated the effect of problem-based learning through cognition-based tasks on speaking proficiency of Iranian intermediate EFL learners in comparison to the effect of objective-based tasks. The findings of this study proved that not only does problem-based learning through cognition-based tasks has a significant effect on speaking proficiency of intermediate Iranian EFL learners, but also this effect is greater than that of objective-based tasks.

Larsson (2001, p.2) stated that "PBL can be used to scaffold students social skills". Considering that speaking ability is also a social skill, it can be claimed that the findings of the current study are congruent with findings of the study carried out by Larsson (2001). Also, the findings of this study are in line with the findings of Albanese and Mitchell (1993) and Vernon and Blake (1993) indicating that meta-analyses of PBL proved that learners performed better than traditional learners at tasks related to problem solving, as in the current study the students could also outperform those students who followed traditional approaches to language education in form of objective-based tasks.

Hmelo (1998) also believes that the students in the PBL curriculum were more likely to produce accurate and coherent explanations than students in the traditional curriculum. Considering that coherence and accuracy were two of the factors that were rated in this study, it can be claimed that the current study is in accordance with the findings of Hmelo (1998). Moreover, Barrows and Tamblyn (1980) argue that PBL can assist learners become active because of its emphasis on learning in real-world problems and making learners responsible for their learning. This research also revealed that learners took most of the class time and the teachers' role, as opposed to many traditional language teaching methods, was of a facilitator only.

Lampert (2001) states that from a socio-cultural perspective, in PBL classrooms knowledge is constructed through social interactions. Since no actual teaching was used in the PBL process in this study, it can be concluded that the social interactions the learners had with each other had a significant role in constructing knowledge and helping them become better learners.

Pea and Salomon (1993) also believe that tackling problems in a PBL setting can be carried out more effectively than the time the learners study individually. This study also proved that in a learning context in which students make extensive use of their peers the outcome of the course can outperform the situation students try to solve the problems alone. In addition, Abdullah and Hayati (1998) posit that PBL can situate language learning by posing problems identical to those in real life. This study also proved what was already stated by Abdullah and Hayati (1998) is more than a conjecture and can possibly be fulfilled if a precise tutorial process is defined for the class.

Finally, according to Norman and Schmidt (1992), the presence of cognitive principles has an important role in success or failure of a PBL project. It can be claimed that PBL is totally a cognition-based process and without the use of learners' cognition, what the learners' do in the classroom is merely a buzz group. It is believed that much of the effect witnessed in this study is due to making use of the learners' cognition. Thus, it can be stated that the findings of this study are in accordance with the findings of Norman and Schimdt (1992).

\section{Conclusion}

The present study tried to investigate the effect of problem-based leaning on speaking proficiency of intermediate Iranian EFL learners' through cognition-based tasks and to compare the effect it has with the effect traditional objective-based tasks have on the speaking proficiency of the learners. A comparison of the intermediate pretest scores with posttest scores in the experimental group through paired sample t-test proved that problem-based learning through 
cognition-based tasks had a significant positive effect on speaking proficiency of intermediate Iranian EFL learners, thus, the first null hypothesis was rejected. In addition, the results gained from independent sample t-test proved that there exists a significant difference between the posttest mean scores of the experimental group and the control group. It further proved that intermediate participants that went through cognition-based tasks had outperformed intermediate participants that went through objective-based tasks instruction. Thus, the second null hypothesis was rejected as well.

The prime suggestion of this study would be directed to educational systems especially those that are in short of human resources and would consider growing more independent students. By implementing PBL in language classes in such settings, students can take control of the teaching-learning process to a very great extent and would need to refer to the teacher only as a source for debriefing already learned materials. In this way, a single teacher can deal with a great number of learners. Secondly, syllabus designers could consider the findings of the current study, as it can greatly influence the timing of language classes and types of tests the learners are required to pass after the course. In terms of timing, more time should be allocated to students than the teacher, and in terms of assessment, the type of assessment used of the courses should be congruent with a special PBL process used in the classroom.

Language teacher and learners could employ problem-based learning in order to scaffold their deep understanding of the subjects, as it is believed that PBL can cause long term retention of knowledge instead of memorization. Material developers could also use the findings of the study to prepare material which make students thing and analyze the subjects instead of memorizing them. In fact, there would be no need to use books with reveal all facts about a task. The central aim of this study was to highlight the importance of implementing interdisciplinary approaches such as problembased learning into EFL/ESL setting. The researcher hopes that this study could shed light on the importance of this issue, and language teachers would consider what has been presented in this study and apply it into their own classes.

The study had some limitations. Firstly, the study was confined by the literature and bibliographical archive of problembased learning. Most of the studies carried out so far with regard to PBL are in the realm of principles such as medicine and business and there is no satisfactory plethora of research in language education. This fact, to a great extent, limited the literature of the study and the research as well. Moreover, the design of the study limited the researcher and the study. Tutored PBL is a notion adopted from medical studies and ought to be defined and piloted precisely before the actual data collection procedure. In order to do so, the researcher made use of Scott's (2004) model to design a complete procedure to teach English speaking with regard to PBL. Also, the study could not consider all influential factors on the data collected with regard to the samples albeit gender, age, first language, background of the participants, thinking style and learning style may affect the results.

Considering the finding of the study, several recommendations for future studies can be discussed. This study delved into the effect of problem-based learning via cognition-based tasks on speaking proficiency of the learners, yet other language skills i.e. listening, reading and writing are still untouched. It is highly recommended that future studies focus on these language skills. Moreover, no prior study has yet investigated the relationship between language styles and problem-based learning in EFL/ESL setting. Thus, it is recommended that researchers focus the effect PBL can have on learning the second language with regard to learning styles. In addition, it has become highly recommended by scholars to design new learning processes to carry out PBL in classes. Although a design has been designed by the researcher in this study to teach PBL in language classes, in no way it is claimed to be perfect and it is suggested that researchers should try to enhance the teaching process offered in this thesis. It is also very important to find out if problem-based leaning has any effect of leaning of language subcomponents, that is, vocabulary, grammar and pronunciation. Finally, more studies should be carried out with regard to PBL and the psychological process. It is highly recommended that researchers try to find out which particular cognitive process is at work when PBL is implemented in the classroom.

\section{References}

Abdullah \& Hayati, M. (1998). Problem-based learning in language education: a constructivist model. Eric publications.

Abrandt Dahlgren, M., \& Dahlgren, L. O. (2002). Portraits of PBL: Students' experiences of the characteristics of problem-based learning in physiotherapy, computer engineering, and psychology. Instr. Sci. 30, 111-127.

Albanese, M. A., \& Mitchell, S. (1993). Problem-based learning: A review of literature on its outcomes and implementation issues. Acad. Med. 68, 52-81.

Anita, E., Woolfolk, P.H., \& Winne Nancy, E.P. (2011) Educational psychology. Rahnama Press. p.197

Barrows, H. S. (2000). Problem-based learning applied to medical education, Southern Illinois University Press, Springfield.

Barrows, H., \& Kelson, A. C. (1995). Problem-based learning in secondary education and the problem-based learning institute (Monograph 1), Problem-Based Learning Institute, Springfield, IL.

Barrows, H. S., \& Tamblyn, R. (1980). Problem-based learning: An approach to medical education, Springer, New York.

Bereiter, C., \& Scardamalia, M. (1989). Intentional learning as a goal of instruction. In Resnick, L.B. (ed.), Knowing, Learning, and Instruction: Essays in Honor of Robert Glaser, Erlbaum, Hillsdale, NJ, 361-392.

Blumberg, P., \& Michael, J. A. (1992). Development of self-directed learning behaviors in a partially teacher-directed problem-based learning curriculum. Teach. Learn. Med. 4, 3-8.

Blumenfeld, P. C., Marx, R.W., Soloway, E., \& Krajcik, J. S. (1996). Learning with peers: From small group cooperation to collaborative communities. Educ. Res. 25(8), 37-40. 
Boud, D., \& Feletti, G. (1991). The Challenge of Problem Based Learning, St. Martin's Press, New York.

Bransford, J. D., \& McCarrell, N. S. (1977). A sketch of a cognitive approach to comprehension: Some thoughts about understanding what it means to comprehend. In Johnson-Laird,P. N., and Wason, P. C. (eds.), Thinking: Readings in Cognitive Science, Cambridge University Press, Cambridge, UK, pp. 377-399.

Bransford, J. D., Vye, N., Kinzer, C.,\& Risko, R. (1990). Teaching thinking and content knowledge: Toward an integrated approach. In Jones, B. F., and Idol, L. (eds.), Dimensions of Thinking and Cognitive Instruction, Erlbaum, Hillsdale, NJ, 381-413.

Bridges, E. M. (1992). Problem-based learning for administrators, ERIC Clearinghouse on Educational Management, Eugene, OR.

Brown, A. L. (1995). The advancement of learning. Educ. Res. 23(8), 4-12.

Chi, M. T. H., Bassok, M., Lewis, M.W., Reimann, P., \& Glaser, R. (1989). Self-explanations: How students study and use examples in learning to solve problems. Cogn. Sci. 13, 145-182.

Collins, A., Brown, J. S., \& Newman, S. E. (1989). Cognitive apprenticeship: Teaching the crafts of reading, writing, and mathematics. In Resnick, L. B. (ed.), Knowing, Learning, and Instruction: Essays in Honor of Robert Glaser, Erlbaum, Hillsdale, NJ, 453-494.

Derry, S. J., Levin, J. R., Osana, H. P., Jones, M. S., \& Peterson, M. (2000). Fostering students' statistical and scientific thinking: Lessons learned from an innovative college course. Am. Educ. Res. J. 37, 747-773.

Dewey, J. (1938). Experience and Education, Macmillan, New York.

Duch, B. J., Groh, S. E., \& Allen,D. E. (2001). The Power of Problem-Based Learning, Stylus, Steerling, VA.

Ertmer, P., Newby, T. J., \& MacDougall, M. (1996). Students' responses and approaches to case-based instruction: The role of reflective self-regulation. Am. Educ. Res. J. ,33, 719-752.

Evensen, D. (2000). Observing self-directed learners in a problem-based learning context: Two case studies. In Evensen, D., and Hmelo, C. E. (eds.), Problem-Based Learning: A Research Perspective on Learning Interactions, Erlbaum, Mahwah, NJ, 263-298.

Evensen, D. H., Salisbury-Glennon, J.,\& Glenn, J. (2001). A qualitative study of 6 medical students in a problem-based curriculum: Towards a situated model of self-regulation. J. Educ. Psychol ,93, 659-676.

Gallagher, S. A., Stepien,W. J., \& Rosenthal, H. (1992). The effects of problem-based learning on problem solving. Gifted Child Q., 36, 195-200.

Gallow D. (2015). What is Problem-Based Learning? http://www.pbl.uci.edu/whatispbl.htm

Gallagher, S., \& Stepien, W. (1996). Content acquisition in problem-based learning: Depth versus breadth in American studies. J. Educ. Gifted, 19, 257-275.

Greeno, J. G., Collins, A., \& Resnick, L. B. (1996). Cognition and learning. In Berliner, D. C., and Calfee, R. C. (eds.), Handbook of Educational Psychology, Macmillan, New York, 15-46.

Hmelo, C. E. (1998). Problem-based learning: Effects on the early acquisition of cognitive skill in medicine. Journal of the Learning Sciences, 7, 173-208.

Hmelo, C., Shikano, T., Bras, B., Mulholland, J., Realff, M., \& Vanegas, J. (1995). A problembased course in sustainable technology. In Budny, D., Herrick, R., Bjedov, G., and Perry, J. B. (eds.), Frontiers in Education 1995, American Society for Engineering Education, Washington, DC.

Hmelo, C. E., \& Ferrari, M. (1997). The problem-based learning tutorial: Cultivating higher order thinking skills. $J$. Educ. Gifted ,20, 401-422.

Hmelo,C. E., Gotterer,G. S., \& Bransford, J.D. (1997) A theory-driven approach to assessing the cognitive effects of PBL. Instr. Sci., 25, 387-408.

Hmelo, C. E., Holton, D., \& Kolodner, J. L. (2000). Designing to learn about complex systems. J. Learn. Sci. ,9, 247298.

Hmelo-Silver, C. E. (2000). Knowledge recycling: Crisscrossing the landscape of educational psychology in a problembased learning course for preservice teachers. Journal on Excellencein College Teaching, 11, 41-56.

Hmelo-Silver, C. E. (2002). Collaborative ways of knowing: Issues in facilitation. In Stahl, G. (ed.), Proceedings of CSCL 2002, Erlbaum, Hillsdale, NJ, 199-208.

Hmelo-Silver, C. E., \& Barrows, H. S. (2003). Facilitating collaborative ways of knowing. Manuscript submitted for publication.

Kilpatrick, W. H. (1918). The project method. Teach. Coll. Rec. ,19, 319-335.

Kilpatrick, W. H. (1921). Dangers and difficulties of the project method and how to overcome them: Introductory statement: Definition of terms. Teach. Coll. Rec. ,22, 282-288.

Kolodner, J. L. (1993). Case-Based Reasoning, Morgan Kaufmann, San Mateo, CA.

Kolodner, J. L., Hmelo, C. E., \& Narayanan, N. H. (1996). Problem-based learning meets case-based reasoning. In Edelson,D. C., and Domeshek, E. A. (eds.), Proceedings of ICLS 96, AACE, Charlottesville, VA, 188-195.

Koschmann, T. (1999). Editor's introduction: Making meaning of meaning making. Discourse Processes, 27, $103-117$. Koschmann, T., Glenn, P., \& Conlee, M. (1999). Theory presentation and assessment in a problem- based learning group. Discourse Processes, 27, 119-133.

Koschmann, T. D., Myers, A. C., Feltovich, P. J., \& Barrows, H. S. (1994). Using technology to assist in realizing effective learning and instruction: A principled approach to the use of computers in collaborative learning. J. Learn. Sci., 3, 225-262.

Kumaravadivelu, B. (1984) Understanding language teaching: From method to postmethod. Lawrence Erlbaum Associates, Inc. 
Lampert, M. (2001). Teaching Problems and the Problems of Teaching, Yale University Press, New Haven, CT.

Larsson, J. (2001). Problem-based learning: A possible approach to language education? Polonia Institute Jagiellonian University www.nada.kth.se/ jla/docs/PBL.pdf

Lesgold, A., Rubinson, H., Feltovich, P., Glaser, R., Klopfer,D., \& Wang,Y. (1988). Expertise in a complex skill: Diagnosing X-ray pictures. In Chi, M. T. H., Glaser, R., and Farr, M. J. (eds.), The Nature of Expertise, Erlbaum. Hillsdale, NJ, 311-342.

Needham, D. R., \& Begg, I. M. (1991). Problem-oriented training promotes spontaneous analogical transfer. Memoryoriented training promotes memory for training. Mem. Cogn. ,19, 543-557.

Norman, G. R., \& Schmidt. H. G. (1992). The psychological basis of problem based learning.

Norman, G. R., Brooks, L. R., Colle, C., \& Hatala, H. (1998). Relative effectiveness of instruction in forward and backward reasoning. Paper presented at the Annual Meeting of the American Educational Research Association, San Diego, CA.

Norman, G. R., Trott, A. D., Brooks, L. R., \& Smith, E. K. (1994). Cognitive differences in clinical reasoning related to postgraduate training. Teach. Learn. Med., 6, 114-120.

Novick, L. R., \& Hmelo, C. E. (1994). Transferring symbolic representations across nonisomorphic problems. J. Exp. Psychol. Learn. Mem. Cogn., 20, 1296-1321.

Patel,V. L., Groen, G. J., \& Norman, G. R. (1991). Effects of conventional and problem-based medical curricula on problem solving. Acad. Med. ,66, 380-389.

Patel, V. L., Groen, G. J., \& Norman, G. R. (1993). Reasoning and instruction in medical curricula. Cogn. Instr. ,1, 335-378.

Pea, R. D. (1993). Practices of distributed intelligence and designs for education. In Salomon, G., and Perkins, D. (eds.), Distributed Cognitions: Psychological and Educational Considerations, Cambridge University Press, New York, 4787.

Perfetto, G. A., Bransford, J. D., \& Franks, J. J. (1983). Constraints on access in a problemsolving context. Mem. Cogn. ,11,24-31.

Ram, P. (1999). Problem-based learning in undergraduate instruction: A sophomore chemistry laboratory. J. Chem. Educ. , 76, 1122-1126.

Robert M.k.W, \& Kwan C. (1997). The use of problem-based learning in medical education. Journal of Mediacal education, 1(2), p.149.mcmaster.ca/mdprog/.../Use_of_PBL_Article

Salomon, G. (1993). No distribution without individual cognition: A dynamic interactional view. In Salomon, G., and Perkins, D. (eds.), Distributed Cognitions: Psychological and Educational Considerations, Cambridge University Press, New York, 111-138.

Salomon, G., \& Perkins, D. N. (1989). Rocky roads to transfer: Rethinking mechanisms of a neglected phenomenon. Educ. Psychol., 24, 113-142.

Saslow, J., \& Ascher, A. (2008) Top Notch 2. USA: Pearson-Longman

Savery, J. R. (2006). Overview of problem-based learning: definitions and distinctions. Interdisciplinary Journal of Problem-Based Learning 1(1),p.9.http://dx.doi.org/10.7771/1541-5015.1002.

Schmidt, H. G., DeVolder, M. L., De Grave, W. S., Moust, J. H. C., \& Patel, V. L. (1989). Explanatory models in the processing of science text: The role of prior knowledge activation through small-group discussion. J. Educ. Psychol. ,81, 610-619.7

Schmidt, H. G., \& Moust, J. H. C. (2000). Factors affecting small-group tutorial learning: A review of research. In Evensen, D., and Hmelo, C. E. (eds.), Problem-Based Learning: A Research Perspective on Learning Interactions, Erlbaum, Mahwah, NJ, 19-51.

Schwartz, D. L.,\& Bransford, J. D. (1998). A time for telling. Cogn. Instr. , 16, 475-522.

Scott, K. S. (2014). A multilevel analysis of problem-based learning design characteristics. Interdisciplinary Journal of Problem-Based Learning, 8,2.

Smilovitz, R. (1996). If not now when?: Education not schooling. Morris Publishing.

Shikano, T., \& Hmelo, C. E. (1996, April). Students' learning strategies in a problem-based curriculum for sustainable technology. Paper presented at American Educational Research Association Annual Meeting, New York.

Stepien, W. J., \& Gallagher, S. A. (1993). Problem-based learning: As authentic as it gets. Educ. Leadersh. ,50(7), 2529.

Torp, L., \& Sage, S. (2002). Problems as Possibilities: Problem-Based Learning for K-12 Education, 2nd ed., ASCD, Alexandria, VA.

Vernon, D. T., \& Blake, R. L. (1993). Does problem-based learning work? : A meta-analysis of evaluative research. Acad. Med. ,68, 550-563.

Vye, N. J., Goldman, S. R., Voss, J. F., Hmelo, C., \& Williams, S. (1997). Complex math problem-solving by individuals and dyads: When and why are two heads better than one? Cogn. Instr. , 15, 435-484.

Woods D. R., Hall F. L., Eyles C. H. ,\& Hrymak A. N. (1996). Tutored versus tutorless groups in problem-based learning. American Journal of Pharmaceutical Education, 60.

http://www.researchgate.net/publication/228450997_Tutored_versus_tutorless_groups_in_problem-based_learning.

Southern Illinois University School of Medicine. 